\title{
REVIEW ARTICLE ON ARBUDA AND ITS AYURVEDIC MANAGEMENT IN VEDIC CONTEXT
}

\section{Dr. Suresh Kumar Jat ${ }^{1}$, Dr. Shikha Sharma ${ }^{2}$, Tulika Sharma ${ }^{3}$}

${ }^{1}$ Associate Professor, Dept. of Roga Nidana Evam Vikriti Vijnana, Jayoti Vidyapeeth Women's, University, Jaipur

${ }^{2}$ Associate Professor, Dept. of Samhita \& Siddant, Jayoti Vidyapeeth Women's University, Jaipur

${ }^{3}$ BAMS $4^{\text {th }} \mathrm{yr}$, Jayoti Vidyapeeth Women's University, Jaipur.

Article Info: Received 04 January 2019; Accepted 26 January. 2020

DOI: https://doi.org/10.32553/jbpr.v9i1.714

Address for Correspondence: Dr. Suresh Kumar Jat

Conflict of interest statement: No conflict of interest

ABSTRACT:

Arbuda (cancer) is one of the most asadhya vyadhi in $20^{\text {th }}$ century and spreading further with continuance and increasing incidence in the 21st century. The word Cancer is derived from the Greek meaning 'CRAB'. Cancer is not new term in Ayurveda .It had already described by great trio of our acharya such as charak samhita, sushruta samhita, asthang hridya. The father of Indian surgery is acharya Sushruta which mentioned granthi and arbuda, In modern it resemble with cancer. Cancer as inflammatory or non-inflammatory swelling and mention them as either Granthi (minor neoplasm) or Arbuda (major neoplasm). Recent study shows that 7 lakh people died with cancer every year in India and mortality rate is higher in male than female.

Keywords: Ayurveda, Arbuda, granthi, cancer.

\section{INTRODUCTION}

Our great treaties has already mentioned that human body is based on

1.Dosha

2. Dhatu

3. Mala

Whenever there is any physiological and pathological change occurs in human body it leads to inflammation (shotha).

\section{CLASSICAL VIEW:}

The disease Arbuda was prevalent during the Vedic period.In Atharvaveda[1] in Atharveda it nomenculture as "APACIT". They presented their views regarding cancer as a swelling superficially or situated in the deeper structure or sometimes as chronic ulcers. Such swelling or lumps can be considered as Arbuda. Acharya Charaka, Sushruta, Vagbhatta have clearly mentioned its Hetu, Lakshana and AnekviddhaUpkrama (variety of treatment) of Arbuda. Moreover specialists regarding the disease did exist in past. Acharya Sushurta has described Arbuda as "The Doshas having vitiated in any part of the body and afflicting the Mamsa, and produce a swelling, which is circular, fixed, slightly painful,big in size, broad based, slowly growing and does not suppurate."[2]Acharya Charkha has described Arbuda as a complication of Vata-Rakta[3]. Acharya Madhava while describing Arbuda opines that the vitiatedDosha afflict the Mamsa and Rakta[4] both to produce a swelling. Sharangdhara agrees with Madhavakara regarding the definition of Arbuda.

\section{ARBUDA:}

According to the description given by Susruta [5].

Arbudas are:-

- Increasing mass of big size

- Globular in shape

- $\quad$ Fixed with deeper structure

- Usually do not suppurate

- Giving occasional pain it can occur in any part of the body.

It can involve Mamsa and Rakta due to vitiation of tridosa. 
Table 1: Classification of Arbuda[6]:

\begin{tabular}{|c|c|c|c|c|c|}
\hline $\begin{array}{l}\text { Depending on } \\
\text { dosha }\end{array}$ & $\begin{array}{l}\text { on the basis of } \\
\text { Dhatu }\end{array}$ & $\begin{array}{l}\text { On the basis of } \\
\text { prognosis }\end{array}$ & $\begin{array}{l}\text { On the basis of } \\
\text { Metastasis }\end{array}$ & On the basis of site & $\begin{array}{l}\text { On the basis of } \\
\text { treatment }\end{array}$ \\
\hline $\begin{array}{l}\text { 1.vataj } \\
\text { 2.pittaj } \\
\text { 3.kaphaj } \\
\text { 3.tridoshaj }\end{array}$ & $\begin{array}{l}\text { 1.Medaj } \\
\text { 2.Mamsaj } \\
\text { 3.Raktaj }\end{array}$ & $\begin{array}{l}\text { 1.sadhya } \\
\text { 2.asadhya }\end{array}$ & $\begin{array}{l}\text { 1. Raktarbuda } \\
\text { 2.Adhyarbuda } \\
\text { 3.Dviarbuda }\end{array}$ & $\begin{array}{l}\text { 1.Vartamarbuda } \\
\text { 2. karanarbuda } \\
\text { 3.nasaarbuda } \\
\text { 4.taluarbuda } \\
\text { 5.jalarbuda } \\
\text { 6.galarbuda } \\
\text { 7.mukharbuda } \\
\text { 8.sirarbuda } \\
\text { 9.shukrarbuda }\end{array}$ & $\begin{array}{l}\text { 1. Naveen } \\
\text { 2.Jeeran }\end{array}$ \\
\hline
\end{tabular}

\section{ETIOLOGY:-}

Cancer in each person differs according to the person's exposure to pathogens and genetic constitutions which make each of them to react differently to the same diet. According to principle of Ayurveda, there is no disease without the derangement of Doshas.

Cancer originates due to a metabolic crisis, i.e.

- wrongly adopted lifestyle

- unhealthy food

- poor hygienic condition

- bad habits

Aggravation of Vata factors and suppression of Kapha factors both interacting with one another resulting in proliferation. Similarly, no single cause is assigned to be the causative factor of a particular disease.

\section{PATHOGENESIS OF ARBUD:-}

Acharya Susruta has explained about six stages in the pathogenesis of all diseases.

There are:-

1. Sanchaya- the early stages of localized neoplastic changes

2. Prakopa - transformation of primary growths into metastatic tumours

3. Prasara - metastasis

4. Sthana samsraya - complete metastasis and secondary growth

5. Vyakta - the clinical signs. and symptoms observed

6. Bheda - the stage where differentiation of growth is understood on the basis of histopathology [7].

\section{Management}

Ancient systems of medicines always played vital role in meeting the global health care needs in past, continuing at present and shall also in future. Cancer is the second common cause of death in worldwide and chemotherapy is the commonly used for its treatment Patients, paralised with this disease and suffering from harmful side effects from chemotherapeutic drugs are moving back to natural remedies hoping for a better cure. Ayurvedic medicines protect healthy cells, regulate body metabolism and usually treats the disease. Treatment should be provided by a team of experts in cancer.

\section{Management-1 \\ * Saman chikitsa $\left(1^{\text {st }}\right.$ line of treatment)[8] \\ * Shodhan chikitsa}

\section{Management-2}

* Shalya Tantram- Surgical removal of tumor.

* Srotorodha-clears obstruction of vital pathways.

* Shalya Majja- cutting of the nerves carrying the pain.

\section{Management -3}

* Vyadhi Pratyanika-specific chemotherapy.

* Radiation Therapy

* Rasayana-Ayurvedic immunotherapy.

The goal of immuno therapy is to give substance which enable to resist the growth of cancer in the patient body. These substance are naturallywhich increase the activity of the immune system (increase Ojas).

\section{ROLE OF YOGA IN CANCER [9]:-}

Depending on what parts of body are affected, type of cancer, and physical abilities; yogic practice will be specific. Yoga helps in adjunct to medical treatment by:

1. Ease the symptoms

2. Give more energy

3. Calm the mind and

4. Give tools for accepting, loving and motivation.

\section{ROLE OF PANCHKARMA THERAPY IN ARBUDA:-}

- Removal of impurities from the body.

- Restoration of equilibrium and harmony in the body.

- Removal of negativity and enhancement of an optimistic feeling, improvement of mental, physical, and emotional well-being, and an enhanced sense of self worth. 
- Overall improvement of health and well-being.

\section{CONCLUSION:-}

Ayurveda plays an important complementary role to medicine in treatment efficiency. The most ancient wisdom and science of life, Ayurveda has a long history and its basic principles are valid even today. In addition, more than $80 \%$ of the world population cannot afford modern medicine.Ayurveda and Chemopathy is considered to be ther best, since the side effects are reduced or eradicated by ayurveda. But It is scitifically proven that ayurveda along with yoga and diet can prevent cancer upto to a great extent. Now it is important to raise awareness and encourage implementation of Ayurvedic therapies for combating cancer and suggest an integrated approach in tumor management and treatment. There is enough scope to explore the role of Ayurveda in the management of cancerby analyzing and comparing various concepts mentioned in ancient texts with current

information available in various modern texts with the aim of giving patients relief from undesired effect of cancer like decrease in immunity, decreased quality oflife, poor tolerance to surgery, altered efficacy of chemotherapy and radiotherapy.Various intervention studies have proved the Ayurvedic herbs enhance the quality of life during cancer chemotherapy/radiation. The research on majority of Ayurvedic drugs is in the pre-clinical phase or is not being actively pursued. Future research on arbuda would help to identify safe and effective anticancer drugs. Ayurvedic medicine should be included in clinical trials to increase the lifespan and quality of life of cancer patients. Ayurvedic practitioners and researchers can help to improve this medicine by increasing their involvement.Ayurveda may cure cancer $100 \%$ in upcoming future.

\section{REFERANCE:}

1. 1.K.L. Joshi, Kandas, Chaukhamba Orientali Varanasi, 2000, Atharvaveda Samhita 11/9/1-25, p 336-338

2. P.V. Sharma, Agneevesha, Charaka, Dridhbala, Charaka Chikitsa, Chikitsa Sthana (29/32) Chaukambha Orientalia, Varanasi, 1983, p 924

3. Narendra Shastri, Madhavkar, Madhav Nidanam, Motilal Banarsidas Publications,Delhi, 39/18-19, p 543

4. Susruta samhita, Ayrvedatatwa sandeepika, hindi commentary, edited by Kaviraj ambikashastri, Nidanasthana, Granthyaapchiarbudaadhyaya 11/3, chaukambha Sanskrit sansthana,Edition-2007,pg270

5. Sastry JLN. Introduction to oncology, cancer in Ayurveda. Varanasi: Chaukhambha orientalia; 2001. p. 1-24.

6. Dr.J.L.N. Sastry, Introduction to oncology Cancer in Ayurveda, Chaukhambha orientalia Varanasi, Reprint edition: 2016, P. No. - 11-12.

7. Prof. A.K. Jain, Textbook of physiology vol-I, avichal publishing company, P.N.- 511. 